\title{
KONSEP DAN TEORI KURIKULUM DALAM DUNIA PENDIDIKAN
}

\author{
Nur Ahid*
}

\begin{abstract}
The concept of curriculum develops along side with the development of education. It is also varied according to schools of thought and the theories it upholds. The value of curriculum cannot be looked at only from the written document. It must also be judged from its implementation in the classes. Curriculum is not merely a written teaching plan. It is also a function that operates in the classes, a guideline and regulations for both the milieu and activities in these classes. For this reason, curriculum can be understood as a set of regulations that a student must undergo in order to achieve certain degree or certificate. In the meantime, theory is a set of statements that are orderly structured in a way that give functional meaning to a series of events. The theory of curriculum includes: the concept of curriculum, its assignment, development, design, implementation and evaluation. There are three concepts however in relation to curriculum, namely (1) curriculum as a substance, (2) curriculum as a system, and (3) curriculum as a field of study. Concerning the later, curriculum has become the subject of study by the experts in the field of education and teaching. The aim of curriculum as a field of study is to develop a science of curriculum and its system.
\end{abstract}

Keywords: concept of education, theory of education, curriculum

\section{Pendahuluan}

Kurikulum dan pendidikan merupakan dua konsep yang harus dipahami terlebih dahulu sebelum membahas mengenai pengembangan kurikulum. Sebab, dengan pemahaman yang jelas atas kedua konsep tersebut diharapkan para pengelola pendidikan, terutama pelaksana kurikulum, mampu melaksanakan tugasnya dengan sebaik-baiknya. Kurikulum dan Pendidikan bagaikan dua keping uang, antara yang satu dengan yang lainnya saling berhubungan dan tak bisa terpisahkan.

Secara kodrati, manusia sejak lahir telah mempunyai potensi dasar (fityah) ${ }^{1}$ yang harus ditumbuhkembangkan agar fungsional bagi kehidupannya di kemudian hari. Untuk itu, aktualisasi terhadap potensi tersebut dapat dilakukan usaha-usaha yang disengaja dan secara sadar agar mencapai pertumbuhan dan perkembangan secara optimal.

Pendidikan, sebagai usaha dan kegiatan manusia dewasa terhadap manusia yang belum dewasa, bertujuan untuk menggali potensi-potensi tersebut agar menjadi aktual dan dapat dikembangkan. ${ }^{2}$ Dengan begitu, pendidikan adalah alat untuk memberikan rangsangan agar potensi manusia tersebut berkembang sesuai dengan apa yang diharapkan. Dengan berkembangnya potensi-potensi itulah manusia akan menjadi manusia dalam arti yang

\footnotetext{
* STAIN Kediri, JI. Sunan Ampel 7 Ngronggo Kediri, e-mail: stainkediri@ yahoo.com, telepon: 08175021735.

${ }^{1}$ Fitrah di sini dimaksudkan sebagai potensi dasar manusia yang dibawa sejak lahir, di antaranya adalah agama, intelek, sosial, susila, seni, ekonomi, kawin, kemajuan, persamaan, keadilan, kemerdekaan, politik, ingin dihargai, dihormati dan lain sebagainya. Lihat Nur A hid, "Konsep Pendidikan Islam dalam Keluarga", (Tesis, IAIN Sunan Kalijaga, Yogyakarta, 1993), 20

${ }^{2}$ Ibid., 20. Lihat juga Sudirman, Ilmu Pendidikan (Bandung: Remaja Rosdakarya, 1987), 4.
} 
sebenaruya. Di sinilah, pendidikan sering diartikan sebagai upaya manusia untuk memanusiakan manusia. Sehingga mampu memenuhi tugasnya sebagai manusia dan menjadi warga negara yang berarti bagi suatu negara dan bangsa. ${ }^{3}$

Pendidikan dapat terjadi melalui interaksi manusia dengan lingkungannya, baik lingkungan fisik maupun sosial. Proses interaksi tersebut akan berlangsung dan dialami manusia selama hidupnya. Interaksi manusia dalam lingkungan sosialnya menempatkan manusia sebagai mahluk sosial. Yakni, makhluk yang saling memerlukan, saling bergantung, dan saling membutuhkan satu sama lain, termasuk ketergantungan dalam hal pendidikan. Di samping itu, manusia sebagai makhluk sosial terikat dengan sistem sosial yang lebih luas. Dalam sistem itu didukung oleh nilai-nilai dan norma-norma yang dimiliki dan diyakini oleh masyarakat yang bersangkutan. Keterikatan itu menempatkan manusia menyatu dengan nilai-nilai yang sifatnya universal. Karena itu, manusia dapat dikatakan sebagai makhluk yang mempunyai kesadaran moral dan keagamaan.

Sekolah, sebagai bagian dari sistem pendidikan nasional, tidak dapat dipisahkan dari sistem kehidupan sosial yang lebih luas. Artinya, sekolah itu harus mampu mendukung terhadap kehidupan masyarakat Indonesia yang lebih baik. Dalam pendidikan sekolah, pelaksanaan pendidikan diatur secara bertahap atau mempunyai tingkatan tertentu. Dalam sistem pendidikan nasional, jenjang pendidikan dibagi menjadi pendidikan dasar, pendidikan menengah, dan pendidikan tinggi. Masing-masing tingkatan itu mempunyai tujuan yang dikenal dengan tujuan institusional atau tujuan kelembagaan, yakni tujuan yang harus dicapai oleh setiap jenjang lembaga pendidikan sekolah. Semua tujuan institusi tersebut merupakan penunjang terhadap tercapainya tujuan pendidikan nasional.

\section{Konsep Kurikulum}

Konsep kurikulum berkembang sejalan dengan perkembangan teori dan praktik pendidikan, juga bervariasi sesuai dengan aliran atau teori pendidikan yang dianutnya. Yang perlu mendapatkan penjelasan dalam teori kurikulum adalah konsep kurikulum. Ada tiga konsep tentang kurikulum, kurikulum sebagai substansi, sebagai sistem, dan sebagai bidang studi. ${ }^{4}$

Konsep pertama, kurikulum sebagai suatu substansi. Kurikulum dipandang sebagai suatu rencana kegiatan belajar bagi murid-murid di sekolah, atau sebagai suatu perangkat tujuan yang ingin dicapai. Suatu kurikulum juga dapat menunjuk kepada suatu dokumen yang berisi rumusan tentang tujuan, bahan ajar, kegiatan belajar-mengajar, jadwal, dan evaluasi. Suatu kurikulum juga dapat digambarkan sebagai dokumen tertulis sebagai hasil persetujuan bersama antara para penyusun kurikulum dan pemegang kebijaksanaan pendidikan dengan masyarakat. Suatu kurikulum juga dapat mencakup lingkup tertentu, suatu sekolah, suatu kabupaten, propinsi, ataupun seluruh negara.

Konsep kedua, adalah kurikulum sebagai suatu sistem, yaitu sistem kurikulum. Sistem kurikulum merupakan bagian dari sistem persekolahan, sistem pendidikan, bahkan sistem masyarakat. Suatu sistem kurikulum mencakup struktur personalia, dan prosedur kerja bagaimana

${ }^{3}$ A zzumardi Azra, Esei-esei Intelektual M uslim Pendidikan Islam (J akarta: Logos Wacana IImu, 1998), 3.

${ }^{4}$ Nana Syaodih Sukmadinata, Pengembangan Kurikulum Teori dan Praktek (Bandung: Remaja Rosdakarya, 2000), 27. 
cara menyusun suatu kurikulum, melaksanakan, mengevaluasi, dan menyempurnakannya. Hasil dari suatu sistem kurikulum adalah tersusunnya suatu kurikulum, dan fungsi dari sistem kurikulum adalah bagaimana memelihara kurikulum agar tetap danamis.

Konsep ketiga, kurikulum sebagai suatu bidang studi yaitu bidang studi kurikulum. Ini merupakan bidang kajian para ahli kurikulum dan ahli pendidikan dan pengajaran. Tujuan kurikulum sebagai bidang studi adalah mengembangkan ilmu tentang kurikulum dan sistem kurikulum. Mereka yang mendalami bidang kurikulum, mempelajari konsep-konsep dasar tentang kurikulum. Melalui studi kepustakaan dan berbagai kegiatan penelitian dan percobaan, mereka menemukan hal-hal baru yang dapat memperkaya dan memperkuat bidang studi kurikulum. ${ }^{5}$

Menurut pandangan lama, kurikulum merupakan kumpulan mata pelajaran yang harus disampaikan guru atau dipelajari oleh siswa. ${ }^{6}$ Anggapan ini telah ada sejak zaman Yunani Kuno. Dalam lingkungan atau hubungan tertentu pandangan ini masih dipakai sampai sekarang, yaitu kurikulum sebagai "... a racecourse of subject matters to be mastered". ${ }^{7}$ Ada pendapat mengatakan bahwa kurikulum: "a course, as a specific fixed course of study, as in school or college, as one leadang to a degree" ${ }^{8}$ Banyak orang tua bahkan juga guru-guru, kalau ditanya tentang kurikulum akan memberikan jawaban sekitar bidang studi atau mata pelajaran. Lebih khusus mungkin kurikulum diartikan hanya sebagai isi pelajaran.

Dalam hal ini al-Shaybanisebagaimana dikutip H asan Langgulung mengatakan: Kurikulum adalah sejumlah pengalaman pendidikan, kebudayaan, sosial, olahraga, dan kesenian yang disediakan oleh sekolah bagi murid-murid di dalam dan di luar sekolah dengan maksud menolongnya untuk berkembang menyeluruh dalam segala segi dan merubah tingkah laku mereka sesuai dengan tujuan-tujuan pendidikan. ${ }^{9}$

Maurit J ohnson mengajukan keberatan terhadap konsep kurikulum yang sangat luas. MenurutJ ohnson, pengalaman hanya akan muncul apabila terjadi interaksi antara siswa dengan lingkungannya. Interaksi seperti itu bukan kurikulum, tetapi pengajaran. Kurikulum hanya menggambarkan atau mengantisipasi hasil dari pengajaran. J ohnson membedakan dengan tegas antara kurikulum dengan pengajaran. Semua yang berkenaan dengan perencanaan dan pelaksanaan, seperti perencanaan isi, kegiatan belajar -mengajar, evaluasi, termasuk pengajaran. Sedangkan kurikulum hanya berkenaan dengan hasil-hasil belajar yang diharapkan dicapai oleh siswa. Menurut J ohnson kurikulum adalah ... a structured series of intended learning

\footnotetext{
${ }^{5}$ Ibid., 27.

${ }^{6}$ Ibid., 4.

${ }^{7}$ Robert S. Azia, Curriculum Principles and Foundation (New York: Harper and Row Publisher, 1976 ), 7.

${ }^{8}$ Webster, Webster's New International Dictionary (t.tp.: GC Company, 1993), 648.

${ }^{9}$ Hasan Langgulung, Manusia dan Pendidikan: Suatu Analisa Psikologik dan Pendidikan (J akarta: Pustaka al-Husna, 1989), 145. Lebih lanjut Langgulung mengatakan bahwa kurikulum mempunyai empat unsur atau aspek, yaitu: 1) tujuan-tujuan yang ingin dicapai oleh pendidikan, 2) pengetahuan (knowledge), informasi-informasi, data-data, aktvitas-aktivitas dan pengalaman-pengalaman dari mana terbentuk kurikulum itu. Bagian inilah yang biasa disebut mata pelajaran. Bagian inilah dimaksud dalam silabus, 3) metode dan cara-cara mengajar yang dipakai oleh guruguru untuk mengajar dan mendorong murid-murid belajar dan membawa ke arah yang dikehendaki oleh kurikulum, dan 4) metode dan cara penilaian yang dipergunakan dalam mengukur dan menilai kurikulum dan hasil proses pendidikan yang direncanakan dalam kurikulum seperti ujian triwulan, semesteran dan lain-lain.
} 
outcome. ${ }^{10}$

Terlepas dari pro dan kontra terhadap pendapat MauritJ ohnson, beberapa ahli memandang kurikulum sebagai rencana pendidikan atau pengajaran. Salah seorang di antara mereka adalah Mac Donald. Menurut dia, sistem persekolahan terbentuk atas empat subsistem, yaitu; mengajar, belajar, pembelajaran, dan kurikulum. ${ }^{11}$ Mengajar (teaching) merupakan kegiatan atau perlakuan profesional yang diberikan oleh guru. Belajar (learning) merupakan kegiatan atau upaya yang dilakukan siswa sebagai respons terhadap kegiatan mengajar yang diberikan oleh guru. Keseluruhan pertautan kegiatan yang memungkinkan dan berkenaan dengan terjadinya interaksi belajar-mengajar disebut pembelajaran (instruc-tion). Kurikulum (curriculum) merupakan suatu rencana yang memberi pedoman atau pegangan dalam proses kegiatan belajar-mengajar.

Kurikulum juga sering dibedakan antara kurikulum sebagai rencana (curriculum plan) dengan kurikulum yang fungsional (functioning curricu-lum). Menurut Beauchamp " $A$ curriculum is a written document which may contain many ingredients, but basically it is a plan for the education of pupils during their enrollment in given school". ${ }^{12}$ Beauchamp lebih memberikan tekanan bahwa kurikulum adalah suatu rencana pendidikan atau pengajaran. Pelaksanaan rencana itu sudah masuk pengajaran. Selanjutnya, Zais menjelaskan bahwa kebaikan suatu kurikulum tidak dapat dinilai dari dokumen tertulisnya saja, melainkan harus dinilai dalam proses pelaksanaan fungsinya di dalam kelas. Kurikulum bukan hanya merupakan rencana tertulis bagi pengajaran, melainkan sesuatu yang fungsional yang beroperasi dalam kelas, yang memberi pedoman dan mengatur lingkungan dan kegiatan yang berlangsung di dalam kelas. Rencana tertulis merupakan dokumen kurikulum (curriculum document or, inert curriculum), sedangkan kurikulum yang dioperasikan di kelas merupakan kurikulum fungsional (functioning, live or operative curriculum).

Hilda Taba mempunyai pendapat yang berbeda dengan pendapat-pendapatitu. Perbedaan antara kurikulum dan pengajaran menurut dia bukan terletak pada implementasinya, tetapi pada keluasan cakupannya. Kurikulum berkenaan dengan cakupan tujuan isi dan meto de yang lebih luas atau lebih umum, sedangkan yang lebih sempit, lebih khusus menjadi tugas pengajaran. Menurut Taba keduanya membentuk satu kontinum. Kurikulum terletak pada ujung tujuan umum atau tujuan jangka panjang, sedangkan pengajaran pada ujung lainnya yaitu yang lebih khusus atau tujuan dekat. ${ }^{13}$ Untuk lebih memahami lebih jelas dapat dilihat pada gambar di halaman 16.

\footnotetext{
${ }^{10}$ Mauritz J ohnson, Intentionality in Education (New York: Center for Curriculum Research and Services, 1967), 130.

${ }^{11}$ J ames B. MacD onald, Educational Models for Instruction (Washington DC: The Association for Supervision and Curriculum Development, 1965), 3.

${ }^{12}$ George A. Beauchamp, Curriculum Theory (Wilmette, Illinois: The KAGG Press, 1975), 6.

${ }^{13} \mathrm{Hilda}$ Taba, Curriculum Development: Theory and Practices (N ew York: Harcourt, Brace and World, Inc., 1962), 37.
} 


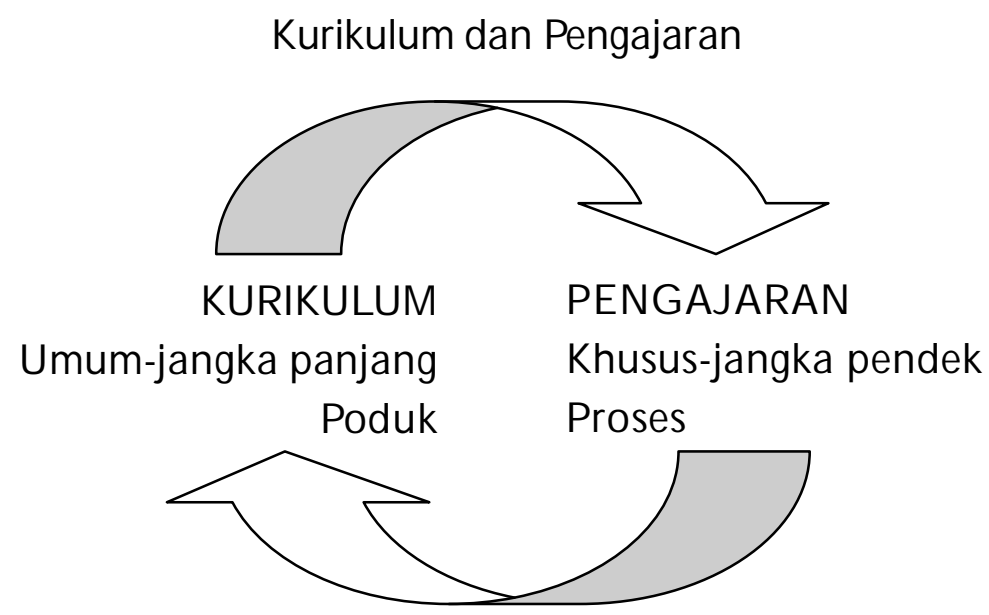

Menurut G eorge A. Beauchamp, kurikulum sebagai bidang studi membentuk suatu teori, yaitu teori kurikulum. Beauchamp mendefinisikan teori kurikulum sebagai ... a set of related statements that give meaning to a schools, curriculum by pointing it the relationships among its ele-ments and by directing its development, its use, and its evaluation. ${ }^{14}$

\section{Teori Kurikulum}

Teo ri merupakan suatu perangkat pernyataan yang bertalian satu sama lain, yang disusun sedemikian rupa sehingga memberikan makna yang fungsional terhadap serangkaian kejadian. Perangkat pernyataan tersebut dirumuskan dalam bentuk definisi deskriptif atau fungsional, suatu konstruksi fungsional, asumsi-asumsi, hipotesis, generalisasi, hukum, atau term-term. Isi rumusanrumusan tersebut ditentukan oleh lingkup dari rentetan kejadian dicakup, jumlah pengetahuan empiris yang ada, dan tingkat keluasan dan kedalaman teori dan penelitian di sekitar kejadiankejadian tersebut.

Kalau konsep-konsep itu diterapkan dalam kurikulum, maka dapatlah dirumuskan tentang teori kurikulum, yaitu sebagai suatu perangkat pernyataan yang memberikan makna terhadap kurikulum sekolah. Makna tersebut terjadi karena adanya petunjuk perkembangan, penggunaan dan evaluasi kurikulum. Bahan kajian dari teori kurikulum adalah hal-hal yang berkaitan dengan penentuan keputusan, penggunaan, perencanaan, pengembangan, evaluasi kurikulum, dan lain-lain.

Menurut Bobbit, inti teori kurikulum itu sederhana, yaitu kehidupan manusia. ${ }^{15}$ Kehidupan manusia meskipun berbeda-beda pada dasarnya sama, terbentuk oleh sejumah kecakapan pekerjaan. Pendidikan berupaya mempersiapkan kecakapan-kecakapan tersebut dengan teliti dan sempurna. Kecakapan-kecakapan yang harus dikuasai untuk dapat terjun dalam kehidupan sangat bermacam-macam, bergantung pada tingkatannya maupun jenis lingkungan. Setiap tingkatan dan lingkungan kehidupan menuntut penguasaan pengetahuan, keterampilan, sikap, kebiasaan, apresiasi tertentu. Hal-hal itu merupakan tujuan kurikulum. Untuk mencapai hal-hal itu ada serentetan pengalaman yang harus dikuasai anak. Seluruh tujuan beserta pengalaman-pengalaman tersebut itulah yang menjadi bahan kajian teori kurikulum.

\footnotetext{
${ }^{14}$ Beauchamp, Curriculum Theory, 58-59.

${ }^{15}$ Franklin Babbit, The Curriculum (Boston: Hounghton Mifflin, 1918), 28.
} 
Perkembangan teori kurikulum selanjutnya dibawakan oleh Hollis Caswell. Dalam peranannya sebagai ketua divisi pengembang kurikulum di beberapa negara bagian di Amerika Serikat (Tennessee, Alabama, Florida dan Virginia), ia mengembangkan konsep kurikulum yang berpusat pada masyarakat atau pekerjaan (society centered) maka Caswell mengembangkan kurikulum yang bersifat interaktif. Dalam pengembangan kurikulumnya, Caswell menekankan pada partisipasi guru, berpartisipasi dalam menentukan kurikulum, menentukan struktur organisasi dari penyusunan kurikulum, dalam merumuskan pengertian kurikulum, merumuskan tujuan, memilih isi, menentukan kegiatan belajar, desain kurikulum, menilai hasil, dan sebagainya. ${ }^{16}$

Ralph W. Tylor (1949) sebagaimana dikutip Sukmadanata mengemukakan empat pertanyaan pokok yang menjadi inti kajian kurikulum: 1) Tujuan pendidikan yang manakah yang ingin dicapai oleh sekolah? 2) Pengalaman pendidikan yang bagaimanakah yang harus disediakan untuk mencapai tujuan tersebut? 3) Bagaimana mengorganisasikan pengalaman pendidikan tersebut secara efektif? 4) Bagaimana kita menentukan bahwa tujuan tersebut telah tercapai?. ${ }^{17}$

Beauchamp merangkumkan perkembangan teori kurikulum antara tahun 1960 sampai dengan 1965. la mengidentifikasi adanya enam komponen kurikulum sebagai bidang studi, yaitu: landasan kurikulum, isi kurikulum, desain kurikulum, rekayasa kurikulum, evaluasi dan penelitian, dan pengembangan teori. ${ }^{18}$

Thomas L. Faix (1966) menggunakan analisis struktural-fungsional yang berasal dari biologi, sosiologi, dan antropologi untuk menjelaskan konsep kurikulum. Fungsi kurikulum dilukiskan sebagai proses bagaimana memelihara dan mengembangkan strukturnya.

Ada sejumlah pertanyaan yang diajukan dalam analisis struktural-fungsional ini. Topik dan subtopik dari pertanyaan ini menunjukkan fenomena-fenornena kurikulum. Pertanyaanpertanyaan itu menyangkut: (1) pertanyaan umum tentang fenomena kurikulum, (2) sistem kurikulum, (3) unit analisis dan unsur--unsurnya, (4) struktur sistem kurikulum, (5) fungsi sistem kurikulum, (6) proses kurikulum, dan (7) prosedur analisis struktural-fungsional.

Alizabeth S. Maccia sebagaimana dikutip Sukamadanata dari hasil analisisnya menyimpulkan adanya empat teori kurikulum, yaitu: (1) teori kurikulum, (2) teori kurikulumformal, (3) teori kurikulum evaluasional, dan (4) teori kurikulum praksiologi. ${ }^{19}$

Maurit J ohnson (1967) membedakan antara kurikulum dengan proses pengembangan kurikulum. Kurikulum merupakan hasil dari sistem pengembangan kurikulum, tetapi sistem pengembangan bukan kurikulum. MenurutJ ohnson, kurikulum merupakan seperangkat tujuan belajar yang terstruktur. J adi, kurikulum berkenaan dengan tujuan dan bukan dengan kegiatan. Berdasarkan rumusan kurikulum tersebut, pengalaman belajar anak menjadi bagian dari pengajaran. ${ }^{20}$

${ }^{16}$ Ronald Doll Caswel, Curriculum Improvement: Decision Making and Process (Boston: Allyn Bacon Inc., 1974), 46.

${ }^{17}$ Sukmadinata, Pengembangan Kurikulum, 29.

${ }^{18}$ Beauchamp, Curriculum, 68.

${ }^{19}$ Sukmadinata, Pengembangan Kurikulum, 31.

${ }^{20}$ J ohnson, Intentionality, 108. 
Sukmadanata mengemukakan tiga unsur dasar kurikulum, yaitu aktor, artifak, dan pelaksanaan. ${ }^{21}$ Aktor adalah orang-orang yang terlibat dalam pelaksanaan kurikulum. Artifak adalah isi dan rancangan kurikulum. Pelaksanaan adalah proses interaksi antara aktor yang melibatkan artifak. Studi kurikulum menurut Frymier meliputi tiga langkah; perencanaan, pelaksanaan, dan evaluasi.

Kata kurikulum, berasal dari bahasa Latin (Yunani), yakni cucere yang berubah menjadi kata benda curriculum. Kurikulum, jamaknya curicula, pertama kali dipakai dalam dunia atletik.

Dalam dunia atletik, kurikulum diartikan a race course, a place for running a chariot. ${ }^{22}$ Suatu jarak untuk perlombaan yang harus ditempuh oleh seorang pelari. Sedangkan a chariot diartikan semacam kereta pacu pada zaman dulu, yakni suatu alat yang membawa seseorang dari start sampai finish. ${ }^{23}$

Perkembangan lebih lanjut, kurikulum dipakai juga dalam dunia pendidikan. Dalam dunia pendidikan, kurikulum mempunyai arti sebagai berikut:

a. Kurikulum dalam arti sempit atau tradisional

Dalam arti sempit atau tradisional, kurikulum sebagai a course, as a specific fixed course of study, as in school or college, as one leading to a degree. ${ }^{24}$ Dalam pengertian ini, kurikulum sebagai sejumlah mata pelajaran di sekolah atau di perguruan tinggi yang harus ditempuh untuk mendapatkan ijazah atau naik tingkat.

Carter V. Good mengemukakan pengertian kurikulum adalah a systematic group of course or subject required for graduation in major field of study. ${ }^{25}$ Kurikulum merupakan sekumpulan mata pelajaran atau sekwens yang bersifat sistematis yang diperlukan untuk lulus atau mendapatkan ijazah dalam bidang studi pokok tertentu. Robert Zaiz berpendapat curriculum is a resources of subject matters to be mastered. ${ }^{26}$ Kurikulum adalah serangkaian mata pelajaran yang harus dikuasai.

Dari pengertian di atas dapat dikatakan bahwa kurikulum adalah sejumlah mata pelajaran yang disajikan guru kepada siswa untuk mendapatkan ijazah atau naik tingkat. Pengertian kurikulum ini, saat sekarang, sama dengan "rencana pelajaran di sekolah, yang disajikan guru kepada murid." Arieh Levy mengemukakan, kurikulum semacam ini, tidak lebih dari daftar singkat mengenai sasaran dan isi pendidikan yang diajarkan di sekolah atau program silabus atau pokok bahasan yang akan diajarkan. ${ }^{27}$

Dalam hubungan ini, Paul Langrand mengemukakan, kurikulum seperti di atas mempunyai kaitan hanya sedikit pada kehidupan, terlepas dari kenyataan yang konkret, sehingga terjadi jurang antara pengalaman dan pendidikan, dan tidak adanya segala macam bentuk tanya jawab atau keikut-sertaan murid di dalam proses pendidikan. ${ }^{28}$

\footnotetext{
${ }^{21}$ Sukmadinata, Pengembangan Kurikulum, 32.

${ }^{22}$ Webster, Webster's New Dictionary of American Language (t.tp.: The World Publisshing Company, 1964), 361-62

${ }^{23}$ S. Nasution, Azas-azas Kurikulum (t.tp.: J ermars, 1982), 7.

${ }^{24}$ Webster, Webster's New International Dictionary (t.tp.: GG Merriam Company, 1953), 648.

${ }^{25}$ Carter V. Good, Dictionary of Education (t.tp.: McG raw-Hill a Book Company, 1959), 113.

${ }^{26}$ Azia, Curriculum, 71.

${ }^{27}$ Arief Lavy, Planing the School Curriculum (Bandung: Bharata Karya Aksara, 1983), 1-2.

${ }^{28}$ Paul Langrand, An Introduction to L ife Long Education, ter. (J akarta: Gunung Agung, 1981), 18.
} 
b. Kurikulum dalam arti luas atau modern

Kurikulum dalam pengertian ini bukan sekedar sejumlah mata pelajaran, tetapi mempunyai cakupan pengertian yang lebih luas. Yakni, sesuatu yang nyata terjadi dalam proses pendidikan.

Pendapat para ahli di bawah ini mencerminkan pengertian kurikulum di atas, antara lain:

1) Ronald Doll mengemukakan bahwa kurikulum ... all the experiences which are offered to learners under the auspices or direction of the school. ${ }^{29}$ Kurikulum meliputi semua pengalaman yang disajikan kepada murid di bawah bantuan atau bimbingan sekolah.

2) William B. Ragan mengartikan kurikulum ... all the experiences of children for which the school accepts responsibility. ${ }^{30}$ Kurikulum adalah semua pengalaman murid di bawah tanggung jawab sekolah.

3) Harold B. Alberty dan Elsie J. Alberty mendefinisikan kurikulum all of the activities that are provided for student by the school constitute, its curriculum. ${ }^{31}$ Kurikulum adalah segala kegiatan yang dilaksanakan sekolah bagi murid-murid.

Dari sejumlah pendapat di atas dapat disimpulkan, kurikulum adalah semua pengalaman, kegiatan, dan pengetahuan murid di bawah bimbingan dan tanggung jawab sekolah atau guru. Pengertian kurikulum ini memberikan implikasi pada program sekolah bahwa semua kegiatan yang dilakukan murid dapat memberikan pengalaman belajar. Kegiatan-kegiatan tersebut dapatmeliputi kegiatan di dalam kelas. Misalnya, kegiatan dalam mengikuti proses belajar- mengajar (tatap muka), praktek keterampilan, dan sejenisnya, atau kegiatan di luar kelas, seperti kegiatan pramuka, wisata karya, kunjungan ke tempattempat wisata/sejarah, peringatan hari-hari besar nasional dan keagamaan, dan sejenisnya. Bahkan, semua kegiatan yang berhubungan dengan pergaulan antara murid dengan guru, murid dengan murid, murid dengan petugas sekolah, dan pengalaman hidup murid sendiri. Tegasnya, pengertian kurikulum ini mengandung cakupan yang luas, karena meliputi semua kegiatan murid, pengala-man murid, dan semua pengaruh, baik fisik maupun non fisik terhadap pertumbuhan dan perkembangan murid.

Kurikulum dalam pengertian rencana belajar bersamaan arti dengan pengajaran. Artinya, kurikulum itu banyak berkaitan dengan rencana dan cita--cita yang ingin dicapai, sedangkan pengajaran terletak pada perwujudan atau pelaksanaan rencana itu dalam kegiatan belajar-mengajar. Itulah sebabnya, pengembangan kurikulum sama artinya dengan pengembangan pengajaran. Perbedaan kurikulum dengan pengajaran terletak bukan pada implementasinya, melainkan pada keluasan cakupannya. Kurikulum berkenaan dengan tujuan, isi, dan metode yang lebih luas, sedangkan yang lebih sempit menjadi tugas pengajaran. Dengan kata lain, kurikulum berhubungan dengan apa yang ingin dicapai (tujuan), sedangkan pengajaran berkaitan dengan bagaimana mencapai tujuan itu (prosedur).

\footnotetext{
${ }^{29}$ Ronald Doll, Curriculum Improment Decision Making and Process (t.tp.: Ally and Bacon, 1974), 22.

${ }^{30}$ William B. Ragan, Modern Elementary Curriculum (t.tp.: Holt Rinehart and Winston Inc., 1974), 44.

${ }^{31}$ Harold B Alberty and Elsie J AlBerty, Reorganizing the High School Curriculum, $3^{\text {rd }}$ ed. (t.tp.: The Macmillan Company, 1952), 125.
} 
Perbedaan tersebut mengakibatkan perbedaan pendekatan terhadap persoalan keduanya. Persoalan kurikulum dapat dipecahkan atas dasar nilai, sedangkan persoalan pengajaran dapat dipecahkan melalui pendekatan empirik. ${ }^{32}$

Olivia menunjukkan kemungkinan hubungan antara kurikulum dengan pengajaran, sebagai berikut: ${ }^{33}$

1) Model dualistis menggambarkan kurikulum dan pengajaran terpisah. Perencanaan dan pelaksanaan tidak serasi keduanya dapat dilukiskan dalam bagan berikut:
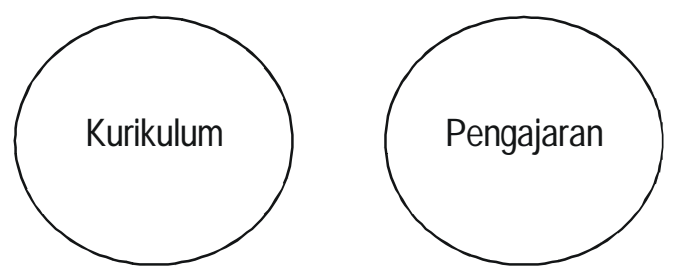

2) Model berkaitan menggambarkan bagian-bagian esensial yang terpadu. Hubungan tersebut dapat dilihat pada bagan di bawah ini:

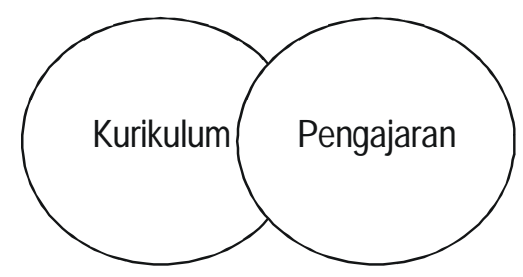

3) Model konsentris menggambarkan kurikulum berhubungan dengan pengajaran, dengan kemungkinan kurikulum dalam pengajaran atau pengajaran di dalam kurikulum, yang satu menjadi subsistem yang lain, atau yang satu bergantung pada lainnya
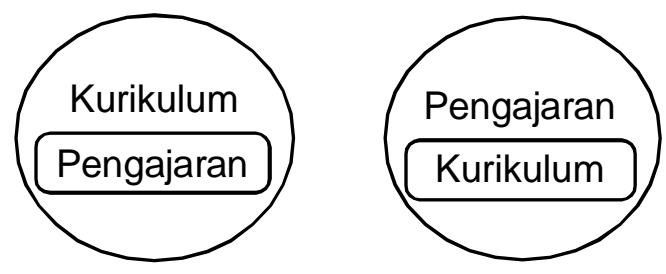

4) Model siklus melukiskan hubungan timbal balik antara kurikulum dan pengajaran, keduanya saling mempengaruhi. Keputusan kurikulum mendahului keputusan pengajaran. Sebaliknya, keputusan pengajaran akan mempengaruhi peningkatan kurikulum (sesudah evaluasi). Hubungan keduanya dapat digambarkan pada bagan berikut:

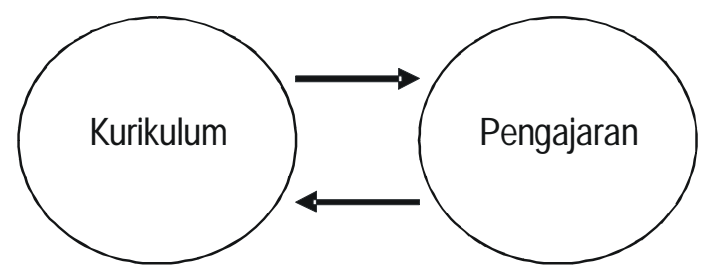

\footnotetext{
${ }^{32}$ W. J ames Popham and Eva L. Baker, Estabilishing Instructional Goals, ter. (Yogyakarta: Kanisius, 1984), 79-80. ${ }^{33}$ O livia dalam Achatus Kaber, Pengembangan Kurikulum (J akarta: Departemen Pendidikan dan Kebudayaan, 1988), 13.
} 
B etapapun ragamnya pengertian kurikulum, sebagaimana dijelaskan di atas, namun pada hakikatnya, kurikulum itu adalah alat/sarana untuk mencapai tujuan pendidikan. $\mathrm{Hal}$ ini, seperti dikemukakan J ohn S. Brubacher whatever its name, it discribes the ground which pupil and teacher cover to reach the goal of education. ${ }^{34}$

\section{Sumber Pengembangan Kurikulum}

Dari kajian sejarah kurikulum, kita mengetahui beberapa hal yang menjadi sumber atau landasan inti penyusunan kurikulum. Pengembangan kurikulum pertama bertolak dari kehidupan dan pekerjaan orang dewasa. Karena sekolah mempersiapkan anak bagi kehidupan orang dewasa, kurikulum terutama isi kurikulum diambil dari kehidupan orang dewasa. Para pengembang kurikulum mendasarkan kurikulumnya atas hasil analisis pekerjaan dan kehidupan orang dewasa.

Dalam pengembangan selanjutnya, sumber ini menjadi luas meliputi semua unsur kebudayaan. Manusia adalah makhluk yang berbudaya, hidup dalam lingkungan budaya, dan turut menciptakan budaya. Untuk dapat hidup dalam lingkungan budaya, ia harus mempelajari budaya, maka budaya menjadi sumber utama isi kurikulum. Budaya ini mencakup semua disiplin ilmu yang telah ditemukan dan dikembangkan para pakar, nilai-nilai adat-istiadat, perilaku, benda-benda, dan lain-lain.

Sumber lain penyusunan kurikulum adalah anak. Dalam pendidikan atau pengajaran, yang belajar adalah anak. Pendidikan atau pengajaran bukan memberikan sesuatu pada anak, melainkan menumbuhkan potensi--potensi yang telah ada pada anak. Anak menjadi sumber kegiatan pengajaran, ia menjadi sumber kurikulum. Ada tiga pendekatan terhadap anak sebagai sumber kurikulum, yaitu kebutuhan siswa, perkembangan siswa, serta minat siswa. J adi, ada pengembangan kurikulum bertolak dari kebutuhan-kebutuhan siswa, tingkat-tingkat perkembangan siswa, serta hal-hal yang diminati siswa.

Terakhir yang menjadi sumber penentuan kurikulum adalah kekuasaan sosial-politik. Di Amerika Serikat pemegang kekuasaan sosial-politik yang menentukan kebijaksanaan dalam kurikulum adalah board of local education yang mewakili negara bagian. Di Indonesia, pemegang kekuasaan sosial- politik dalam penentuan kurikulum adalah Menteri Pendidikan Nasional yang dalam pelaksanaannya dilimpahkan kepada Dirjen Pendidikan Dasar dan Menengah serta Dirjen Pendidikan Tinggi bekerja sama dengan Balitbang Diknas atau kalau di Departemen Agama dalam pelaksanaannya dilimpahkan kepada Direktur Pendidikan Madrasah dan Ditperta atau Dirjen Pendidikan Islam yang bertanggung jawab langsung kepada Menteri Agama. Dengan adanya Disentralisasi, maka disinilah masing-masing lembaga atau daerah mempunyai otoritas dalam penyusunan kurikulum.

\footnotetext{
34] ohn S. Brubacher, Modern Philosophies of Education, $4^{\text {th }}$ ed. (t.tp.: Tata McGraw Hill Publishing Company,
} 1978), 155. 


\section{Model-model Konsep Kurikulum}

Di dalam kurikulum J ohn D. Neil mengemukakan empat macam konsep, yaitu: kurikulum akademis, humanistis, rekonstruksi sosial dan teknologi. ${ }^{35}$

\section{Konsep Kurikulum Akademik}

Kurikulum akademis ini merupakan model yang pertama dan tertua, sejak sekolah berdiri kurikulumnya seperti ini, bahkan sampai sekarang walaupun telah berkembang tipe-tipe lain, umumnya sekolah tidak dapatmelepaskan tipe ini. Karenya sangat praktis, mudah disusun dan mudah digabungkan dengan tipe-tipe lain.

Kurikulum akademis bersumber dari pendidikan klasik (perenialisme dan esensialisme) yang berorientasi pada masa lalu. Semua ilmu pengetahuan dan nilai-nilai telah ditemukan oleh para pemikir masa lalu. Fungsi pendidikan memelihara dan mewariskan hasil-hasil budaya masa lalu tersebut. Kurikulum ini lebih mengutamakan isi pendidikan. Belajar adalah berusaha menguasai ilmu sebanyak-banyaknya. Orang yang berhasil dalam belajar adalah orang yang menguasai seluruh atau sebagian besar isi pendidikan yang diberikan atau disiapkan oleh guru.

Isi pendidikan diambil dari setiap disiplin ilmu. Sesuai dengan bidang disiplinnya para ahli, masing-masing telah mengembangkan ilmu secara sistematis, logis dan solid. Para guru dan pengembang kurikulum tidak perlu susah payah menyusun dan mngembangkan bahan sendiri. Mereka tinggal memilih bahan materi ilmu yang telah dikembangkan para ahli disiplin ilmu, kemudian mereorganisasikan secara sistimatis, sesuai dengan tujuan pendidikan dan tahap perkembangan siswa yang akan mempelajarinya. G uru sebagai penyampai bahan ajar memegang peranan penting. Mereka harus menguasai semua pengetahuan yang ada dalam kurikulum. la harus menjadi ahli dalam bidang-bidang studi yang diajarkan. Lebih jauh guru dituntut bukan hanya menguasai materi pendidikan, tetapi ia juga menjadi model bagi para siswanya. A pa yang disampaikan dan cara penyampaiannya harus menjadi bagian dari pribadi guru. Guru adalah yang digugu dan ditiru (diikuti dan dicontoh).

Karena Kurikulum akademis sangat mengutamakan pegetahuan, maka pendidikannya lebih bersifat intelektual. Kurikulumnya tidak hanya menekankan pada materi yang disampaikan, dalam perkembangannya secara berangsur-angsur memperhatikan proses belajar yang dilakukan siswa. Proses belajar yang dipilih sangat bergantung pada segi apa yang dipentingkan dalam materi pelajaran tersebut.

J erome Bruner dalam The Process of Education sebagaimana di kutip S. Nasution menyarankan bahwa desain kurikulum hendaknya didasarkan atas struktur disiplin ilmu. Selanjutnya, ia menegaskan bahwa kurikulum suatu mata pelajaran harus didasarkan atas pemahaman yang mendasar yang dapat diperoleh dari prinsip-prinsip yang mendasarinya dan yang memberi struktur kepada suatu disiplin ilmu. ${ }^{36}$

Sekurang-kurangnya ada tiga pendekatan dalam perkembangan kurikulum akademis: Pertama, adalah melanjutkan pendekatan struktur pengetahuan. Murid-murid belajar

${ }^{35} \mathrm{~J}$ ohn D. Neil, Curriculum A Comprehensive Introduction (t.tp.: a Division of Scott Foresman and Company, 1980), 5.

${ }^{36}$ S. Nasution, Azas-azas Kurikulum (Bandung: J emmars, 1982), 26. 
bagaimana memperoleh dan menguji fakta-fakta dan bukan sekedar mengingatnya. Kedua, adalah studi yang bersifat integratif. Pendekatan ini merupakan respons terhadap perkembangan masyarakat yang menuntut model-model pengetahuan yang lebih komprehensif terpadu. Pelajaran tersusun atas satuan-satuan pelajaran, dalam satuan-satuan pelajaran tersebut batas-batas ilmu menjadi hilang. Pengorganisasian tema-tema pengajaran didasarkan atasfenomena-fenomena alam, proses kerja ilmiah dan probema-problema yang ada. Ketiga, pendekatan yang dilaksanakan pada sekolah-sekolah fundamentalis. Mereka tetap mengajar berdasarkan mata pelajaran dengan menekankan membaca, menulis dan memecahkan masalah-masalah yang dihadapi. ${ }^{37}$

2. Kurikulum Humanistik

Dalam pandangan humanisme, kurikulum adalah sesuatu yang dapat menunjang perkembangan anak dalam aspek kepribadiannya. Kurikulum dapat dilihat sebagai suatu proses yang mampu memenuhi kebutuhan individu untuk mencapai integrasi perkembangan dalam menuju aktualisasi (perwujudan) diri.

Pengikut dalam aliran ini meliputi pendidikan Konfluen, Kritisi Radikal, Mistisi Baru. Pendidikan konfluen adalah pendidikan yang memandang anak sebagai satu keseluruhan diri. Kritisi Radikal adalah pendidikan yang bersumber dari aliran Naturalisme atau Romantisme, yang menekankan pendidikannya pada upaya untuk membantu anak menentukan dan mengembangkan sendiri segala potensi yang dimilikinya, dan menciptakan situasi yang memungkinkan anak berkembang secara optimal. Mistikisme Modem adalah aliran yang menekankan pada latihan dan kepekaan, perasaan, dan keluhuran budi pekerti, atau menemukan nilai-nilai dalam latihan sensitivitas, meditasi, atau teknik transpersonal lainnya. ${ }^{38}$

Kurikulum humanistik bertolak dari asumsi bahwa anak adalah pertama dan utama dalam pendidikan. Anak adalah subyek yang menjadi sentral aktivitas pendidikan. Anak memiliki sejumlah potensi, kemampuan, dan kekuatan untuk berkembang sendiri. Para pendidik humanis berpegang juga pada konsep Ge-stalt. Artinya, anak merupakan satu kesatuan yang menyeluruh. Pendidikan diarahkan pada pembinaan yang utuh, bukan pada aspek fisik atau intelektual belaka, melainkan juga pada segi afektif (emosi, perasaan, nilai, dan sejenisnya).

Bertolak dari asumsi di atas, kurikulum H umanisme menekankan pada pendidikan yang integratif (menyeluruh) antara aspek afektif (emosi, sikap, dan nilai) dengan aspek kognitif (pengetahuan dan kecakapan intelektual). Atau dengan kata lain, kurikulum ini menambahkan aspek emosional ke dalam kurikulum yang berorientasi pada subject matter (mata pelajaran).

3. Kurikulum Rekonstruksi Sosial.

Kurikulum Rekonstruksi Sosial ini lebih menekankan pada problem-problem yang dihadapi murid dalam kehidupan masyarakat. Konsepsi kurikulum ini mengemukakan bahwa pendidikan bukanlah merupakan upaya sendiri, melainkan merupakan kegiatan bersama, interaksi, dan kerja sama. Interaksi atan kerja sama dapat terjadi pada siswa dengan guru,

\footnotetext{
${ }^{37}$ Sukmadinata, Pengembangan Kurikulum, 83-84.

${ }^{38}$ Ibid., 21-23.
} 
siswa dengan siswa, siswa dengan orang di lingkungannya. Dengan kerja sama semacam ini, para siswa berusaha memecahkan problem-problem yang dihadapi dalam masyarakat agar menjadi masyarakat yang lebih baik.

Pendidikan, menurut konsepsi kurikulum rekonstruksi sosial ini memiliki pengaruh, mengubah, dan memberi corak baru kepada masyarakat dan kebudayaan. ${ }^{39}$

4. Kurikulum Teknologi

Dalam pandangan teknologi, kurikulum merupakan proses teknologi untuk menghasilkan tuntutan kebutuhan-kebutuhan tenaga yang mampu membuat keputusan.

Penerapan teknologi dalam pendidikan, khususnya kurikulum meliputi dua bentuk, yakni; bentuk perangkat lunak (software) dan perangkat keras (handware). Penerapan teknologi perangkat keras dalam pendidikan dikenal sebagai teknologi alat (tulls technology), sedangkan penerapan teknologi perangkat lunak disebut juga teknologi sistem (system technology). ${ }^{40}$

Teknologi pendidikan dalam arti teknologi alat, lebih menekankan penggunaan alatalat teknologi untuk menunjang efisiensi dan efektivitas pendidikan. Dalam kurikulumnya mengandung rencana-rencana penggunaan berbagai alat dan media, juga model-model pengajaran yang banyak melibatkan penggunaan alat. Contoh model dari pengajaran tersebut adalah pengajaran berprograma, mesin pengajaran, pengajaran modul, pengajaran dengan bantuan alat komputer, dan pengajaran dengan pendekatan sistem.

Dalam arti teknologi sebagai sistem, teknologi pendidikan menekankan penyusunan program atau rencana pelajaran dengan menggunakan sistem. Program pengajaran tersebut bisa semata-mata sistem, dapat juga berupa program sistem yang ditunjang dengan alat dan media, serta bisa juga program sistem yang dipadukan dengan alat dan media pengajaran. Pada bentuk pertama, pengajaran tidak membutuhkan alat dan media yang canggih. Sedangkan pada bentuk kedua, pengajaran tetap berjalan, meski tanpa alat dan media yang canggih, tetapi lebih baik jika alat dan media itu disediakan. Bentuk ketiga, pengajaran tidak berjalan tanpa alat dan media yang canggih. Karena itu, alat dan media sebagai syarat yang berpadu dengan program.

Dengan teknologi diusahakan terjadinya proses belajar mengajar, terutama dalam teknik mengajar dapat dikuasai sepenuhnya sehingga dapat menjamin hasil yang sama. Teknologi pendidikan memberikan dasar ilmiah dan empirik kepada proses belajar mengajar. Pengetrapan teknologi telah dikenal dalam kurikulum 1975, setiap guru diharuskan menggunakan Prosedur Pengembangan Sistem Instruksional (PPSI), Pengajaran Modul, Evaluasi Belajar Tahap Akhir (EBTANAS), dan Sistem Penerimaan Mahasiswa Baru (SIPENMARU), belajar-mengajar berbasis internet dan lain sebagainya.

\section{Kedudukan Kurikulum dalam Pendidikan}

Pendidikan berintikan interaksi antara pendidik dengan peserta didik dalam upaya membantu peserta didik menguasai tujuan-tujuan pendi-dikan. Interaksi pendidikan dapat

39 Ibid., 91-95.

${ }^{40}$ A. H amid Syarif, Pengembangan Kurikulum (Surabaya: Bina Ilmu, 1996), 25-26. 
berlangsung dalam lingkungan keluarga, sekolah, ataupun masyarakat. Dalam lingkungan keluarga, interaksi pendidikan terjadi antara orang tua sebagai pendidik dan anak sebagai peserta didik. Interaksi ini berjalan tanpa rencana tertulis. Orang tua sering tidak mempunyai rencana yang jelas dan rinci ke mana anaknya akan diarahkan, dengan cara apa mereka akan dididik, dan apa isi pendidi-kannya. Orang tua umumnya mempunyai harapan tertentu pada anaknya, mudah-mudahan ia menjadi orang saleh, sehat, pandai, dan sebagainya, tetapi bagaimana rincian sifat-sifat tersebut bagi mereka tidak jelas. J uga mereka tidak tahu apa yang harus diberikan dan bagaimana memberi-kannya agar anak-anaknya memiliki sifat-sifat tersebut.

Pendidikan dalam lingkungan sekolah lebih bersifat formal. Guru sebagai pendidik di sekolah telah dipersiapkan secara formal dalam lembaga pendidikan guru. la telah mempelajari ilmu, keterampilan, dan seni sebagai guru. la juga telah dibina untuk memiliki kepribadian sebagai pendidik. Lebih dari itu mereka juga telah diangkat dan diberi kepercayaan oleh masyarakat untuk menjadi guru, bukan sekadar dengan surat keputusan dari pejabat yang berwenang, tetapi juga dengan pengakuan dan penghargaan dari masyarakat, guru melaksanakan tugasnya sebagai pendidik dengan rencana dan persiapan yang matang. Mereka mengajar dengan tujuan yang jelas, bahan-bahan yang telah disusun secara sistematis dan rinci, dengan cara dan alat-alat yang telah dipilih dan dirancang secara cermat. Di sekolah guru melakukan interaksi pendidikan secara berencana dan sadar. Dalam lingkungan sekolah telah ada kurikulum formal, yang bersifat tertulis. Guru-guru melaksanakan tugas mendidik secara formal, karena itu pendidikan yang berlangsung di sekolah disebut pendidikan formal.

Dalam lingkungan masyarakat pun terjadi berbagai bentuk interaksi pendidikan, dari yang sangat formal yang mirip dengan pendidikan di sekolah dalam bentuk kursus-kursus, sampai dengan yang kurang formal seperti ceramah dan sarasehan. Gurunya juga bervariasi dari yang memiliki latar belakang pendidikan khusus sebagai guru, sampai dengan yang melaksanakan tugas sebagai pendidik karena pengalaman. Kurikulumnya juga bervariasi, dari yang memiliki kurikulum formal dan tertulis sampai dengan rencana pelajaran yang hanya ada pada pikiran penceramah atau moderator sarasehan, atau gagasan keteladanan yang ada pada pemimpin. Interaksi pendidikan yang berlangsung di masyarakat, yang memiliki rancangan dan dilaksanakan secara formal sebenarnya dapat dimasukkan dalam kategori pendidikan formal. Interaksi yang rancangan dan pelaksanaannya kurang formal dapat kita sebut sebagai pendidikan kurang formal (less formal). Karena adanya variasi itu, para ahli pendidikan masyarakat lebih senang menggunakan istilah pendidikan luar sekolah bagi interaksi pendidikan yang berlangsung di masyarakat ini.

Dari hal-hal tersebut di atas dapat diambil kejelasan berkenaan dengan pendidikan formal. Pertama, pendidikan formal memiliki rancangan pendidikan atau kurikulum tertulis yang tersusun secara sistematis, jelas, dan rinci. Kedua, dilaksanakan secara formal, terencana, ada yang mengawasi dan menilai. Ketiga, diberikan oleh pendidik atau guru yang memiliki ilmu dan keterampilan khusus dalam bidang pendidikan. Keempat, interaksi pendidikan berlangsung dalam lingkungan tertentu, dengan fasilitas dan alat serta aturan-aturan permainan tertentu pula. ${ }^{41}$

${ }^{41}$ Sukmadinata, Pengembangan Kurikulum, 2. 
Keterkaitan antara interaksi lingkungan dengan proses belajar-mengajar, pendidik-peserta didik, kurikulum pendidikan, saling mempengaruhi dan sangat menentukan terhadap hasil pendidikan. Untuk lebih jelasnya dapat dilihat tabel gambar berikut ini.

\section{Gambar}

Interaksi Kurikulum dengan Lingkungan Pendidikan

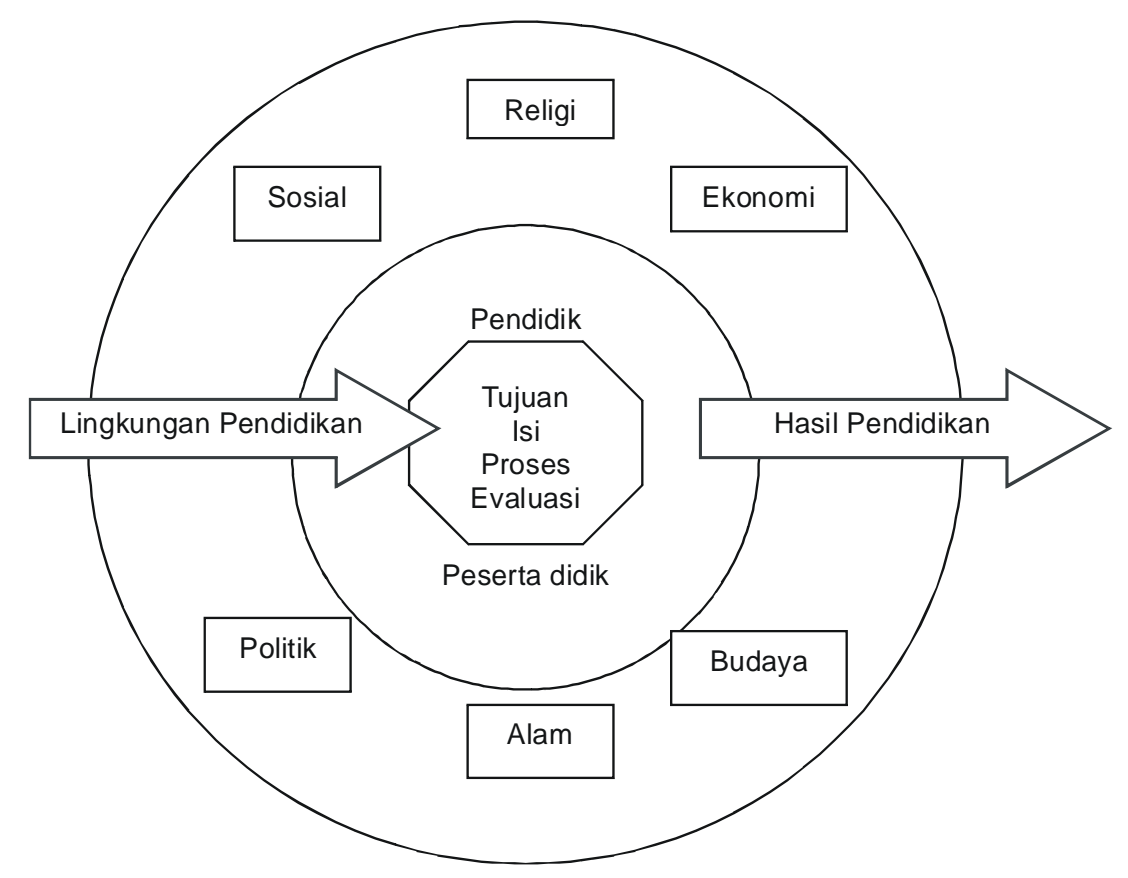

Kurikulum mempunyai kedudukan sentral dalam seluruh proses pendidikan. Kurikulum mengarahkan segala bentuk aktivitas pendidikan demi tercapainya tujuan-tujuan pendidikan. Menurut MauritzJ ohnson kurikulum "prescribes (or at least anticipates) the result of in-struction" ${ }^{42}$ Kurikulum juga merupakan suatu rencana pendidikan, memberikan pedoman dan pegangan tentang jenis, lingkup, dan urutan isi, serta proses pendidikan. Di samping kedua fungsi itu, kurikulum juga merupakan suatu bidang studi, yang ditekuni oleh para ahli atau spesialis kurikulum, yang menjadi sumber konsep-konsep atau memberikan landasan-landasan teoretis bagi pengembangan kurikulum berbagai institusi pendidikan.

\section{Evaluasi Kurikulum}

Evaluasi kurikulum dimaksudkan untuk meneliti kembali, apakah suatu prosesatau kegiatan yang terdapat dalam kurikulum itu telah dan dapat dilaksanakan sesuai dengan perencanaan yang diharapkan. Wright sebagaimana dikutip oleh Sukmadanata mengemukakan bahwa curriculum evaluation may be defined as the estimation of the growth and progress of students toward objectives or values of the curriculum. ${ }^{43}$ Dengan evaluasi kurikulum dimaksudkan suatu estimasi atau perkiraan tentang pertumbuhan dan kemajuan para siswa ke arah pencapaian tujuan-tujuan dan nilai-nilai kurikulum. Luas dan sempitnya program evaluasi kurikulum,

${ }^{42}$ J ohnson, Intentionality, 130.

${ }^{43}$ Sukmadinata, 303. 
sebenarnya ditentukan oleh tujuannya. Apakah evaluasi tersebut ditujukan untuk mengevaluasi keseluruhan komponen-komponen dalam sistem kurikulum atau hanya komponen-komponen tertentu dalam sistem kurikulum tersebut.

Dalam konteks evaluasi kurikulum, kegiatan evaluasi dilakukan pada semua komponen, yang meliputi: 1) Evaluasi penjajakan kebutuhan dan kelayakan kurikulum, 2) Evaluasi pengembangan kurikulum, 3) Evaluasi proses belajar-mengajar, 4) Evaluasi bahan pembelajaran, 5) Evaluasi keberhasilan (produk) kurikulum, dan 6) Penelitian kurikulum atau riset evaluasi kurikulum. ${ }^{44}$ Suatu evaluasi kurikulum, minimal berkenaan dengan tiga hal, yakni evaluasi sebagai moral judgment, evaluasi dan penentuan keputusan, evaluasi dan kosensus nilai. ${ }^{45}$

Secara umum dapat dikatakan bahwa evaluasi kurikulum merupakan usaha untuk memperoleh jawaban atas pertanyaan-pertanyaan berikut:

a. Apakah kesempatan belajar, program, pelajaran, dan kegiatan yang direncanakan dan diorganisasikan itu dapat mencapai tujuan yang diharapkan?

b. Apakah kurikulum yang telah dikembangkan itu dapat diperbaiki dan bagaimana cara memperbaikinya? ${ }^{46}$

Saylor dan Alexander berpendapat bahwa evaluasi adalah proses pengumpulan dan penggunaan informasi sebagai dasar pembuatan keputusan tentang suatu program pendidikan. ${ }^{47}$

Dari pengertian evaluasi di atas, ada tiga komponen dalam evaluasi, yaitu pengumpulan informasi, pembuatan pertimbangan, dan pembuatan keputusan. Ketiga komponen evaluasi tersebut saling berkaitan satu sama lain. Karena itu, dalam proses evaluasi ketiga komponen itu harus dipahami secara jelas.

Komponen informasi merupakan komponen data dasar yang bermanfaat dalam pembuatan pertimbangan. Informasi dapat meliputi data kuantitatif dan kualitatif, umum dan khusus, dan berhubungan dengan manusia, materi, program atau proses. Informasi yang jelas dapat diambil suatu pertimbangan dan keputusan yang akurat.

Komponen pembuatan pertimbangan sebagai hasil penting dari kegiatan penilaian. Ketepatan pertimbangan bergantung atas ketepatan informasi yang diperoleh, sehingga dalam penyampaian informasi, juga harus didasarkan kepada rencana pertimbangan yang akan diambil. Pertimbangan adalah tafsiran dari kondisi sekarang atau prediksi (ramalan) di masa depan. Pengambilan pertimbangan tidak selalu diikuti dengan adanya pengambilan tindakan.

Komponen pengambilan keputusan adalah tujuan akhir dari penilaian. Suatu keputusan menuntut diikutinya suatu tindakan. J adi, misalnya, suatu tim pengembangan kurikulum telah memutuskan suatu kurikulum tersebut baik dan harus dilaksanakan, maka kurikulum tersebut harus dilaksanakan sesuai dengan keputusan tersebut.

${ }^{44}$ O emar Hamalik. Evaluasi Kurikulum (Bandung: Remaja Rosdakarya, 1990), 9.

${ }^{45}$ Sukmadimata, 198.

${ }^{46} \mathrm{~J}$ ohn D M cNeil. Curriculum : A Comprehensive Introduction (Boston: A Division of Scott Foresman and Company, 1990), 35.

${ }^{47}$ Gallen J . Saylor and William A Alexander, Curricullum : Planing for Better Teaching and Learning (t.tp.: Rinehart and Company Int: 1958), 302. 


\section{Penutup}

Dari pembahasan di atas dapat disimpulkan sebagai berikut:

1. Teori adalah suatu perangkat pernyataan yang bertalian satu sama lain, yang disusun sedemikian rupa sehingga memberikan makna yang fungsional terhadap serangkaian kejadian. Cakupan teori kurikulum meliputi: konsep kurikulum, penentuan kurikulum, pengembangan kurikulum, desain kurikulum, implementasi dan evaluasi kurikulum.

2. Teori kurikulum adalah suatu perangkat pernyataan yang memberikan makna terhadap kurikulum sekolah, makna tersebut terjadi karena adanya petunjuk perkembangan, penggunaan dan evaluasi kurikulum. Bahan kajian dari teori kurikulum adalah hal-hal yang berkaitan dengan penentuan keputusan, penggunaan, perencanaan, pengembangan, dan evaluasi kurikulum.

3. Ada tiga konsep tentang kurikulum, yaitu: kurikulum sebagai substansi, sebagai sistem, dan sebagai bidang studi. a) sebagai substansi, yaitu: suatu rencana kegiatan belajar bagi muridmurid di sekolah, atau sebagai suatu perangkat tujuan yang ingin dicapai. Suatu kurikulum juga dapat menunjuk kepada suatu dokumen yang berisi rumusan tentang tujuan, bahan ajar, kegiatan belajar-mengajar, jadwal, dan evaluasi. Suatu kurikulum juga dapat digambarkan sebagai dokumen tertulis sebagai hasil persetujuan bersama antara para penyusun kurikulum dan pemegang kebijaksanaan pendidikan dengan masyarakat. Suatu kurikulum juga dapat mencakup lingkup tertentu, suatu sekolah, suatu kabupaten, propinsi, ataupun seluruh Negara, b) sebagai suatu sistem, yaitu sistem kurikulum merupakan bagian dari sistem persekolahan, sistem pendidikan, bahkan sistem masyarakat. Suatu sistem kurikulum mencakup struktur personalia, dan prosedur kerja bagaimana cara me-nyusun suatu kurikulum, melaksanakan, mengevaluasi, dan menyem-purnakannya. Hasil dari suatu sistem kurikulum adalah tersusunnya suatu kurikulum, dan fungsi dari sistem kurikulum adalah bagaimana memelihara kurikulum agar tetap danamis, dan c) sebagai suatu bidang studi. Ini merupakan bidang kajian para ahli kurikulum dan ahli pendidikan dan pengajaran. Tujuan kurikulum sebagai bidang studi adalah mengembangkan ilmu tentang kurikulum dan sistem kurikulum.

4. Kurikulum adalah seperangkat aturan yang harus dilalui oleh murid, pengalaman, kegiatan, dan pengetahuan murid di bawah bimbingan dan tanggung jawab sekolah atau guru untuk mencapai suatu jenjang tertentu (ijazah). Kurikulum juga merupakan suatu rencana pendidikan, pedoman dan pegangan tentang jenis, lingkup, dan urutan isi, serta proses pendidikan.

5. Empat macam model konsep kurikulum, yaitu: kurikulum akademik, humanik, rekonstruksisosial dan teknologik.

6. Evaluasi kurikulum harus mencakup tiga hal, yaitu produk, efek dan impact. Produk berupa prestasi belajar yang dicapai siswa. Efek adalah perubahan prilaku dalam tingkatan yang lebih tinggi. Impact adalah pengaruh kurikulum pada perkembangan lembaga pendidikan dan masyarakat. 


\section{Daftar Rujukan}

Ahid, Nur. Konsep Pendidikan Islam dalam Keluarga. Tesis, Yogyakarta: IAIN Sunan Kalijaga Yogyakarta, 1993.

Alberty, Harold B and Elsie J. AlBerty. Reorganizing the High School Curriculum, $3^{\text {rd }}$ ed. t.tp.: The Macmllan Company, 1952.

Azia, Robert S. Curriculum Principes and Foundation. t.tp.: Harper \& Row Publisher, 1976.

Azra, Azzumardi. Esei-esei Intelektual M uslim Pendidikan Islam. J akarta: Logos Wacana IImu, 1998.

Beauchamp, George A. Curriculum Theory. Wilmette, Illinois: The KAGG Press, 1975

Brubacher, J ohn S. M odern Philosophies of Education, $4^{\text {th }}$ ed. t.tp.: Tata McG raw H ill Publishing Company, 1978.

Carter V. Good. Dictionary of Education. t.tp.: McG raw-Hill a Book Company, 1959.

Doll, Ronald C. Curriculum Improvement : Decision Making and Process. Boston: Allyn and Bacon, Inc., 1974.

Franklin, Babbit. The Curriculum. Boston: Hounghton Mifflin, 1918.

Hamalik, Oema. Pengembangan Kurikulum. Bandung: Mandar Maju, 1991.

J ohnson, Mauritz. Intentionality in Education. New York: Center for Curriculum Research and Services, 1977.

Langgulung, H asan. Manusia dan Pendidikan: Suatu Analisa Psikologik dan Pendidikan. J akarta:

Pustaka al-H usna, 1989.

Langrand, Paul. An Introduction to Life Long Education, ter. J akarta: Gunung Agung, 1981.

Lavy, Arief. Planing the School Curriculum, ter. Bandung: B harata Karya Aksara, 1983.

MacDonald, J ames B. Educational Models for Instruction. Washington DC: The Association for

Supervision and Curriculum Development, 1965.

Nasution, S. Azas-azas Kurikulum. Bandung: J emmars, 1982.

Neil, J ohn D. Curriculum A Comprehensive Introduction. A Division of Scott Foresman and Company, 1980.

Popham, W. J ames and Eva L. Baker. Estabilishing Instructional Goals, ter. Yogyakarta: Kanisius, 1984.

Sukmadanata, Nana Syaodih. Pengembangan Kurikulum Teori dan Praktek. Bandung: Remaja Rosdakarya, 2000.

Syarif, A. Hamid. Pengembangan Kurikulum. Surabaya: Bina IImu, 1996.

Taba, Hilda, Curriculum Development: Theory and Practices. New York: Harcourt, Brace and World, Inc., 1962.

Undang-Undang No. 2 Tahun 1989 tentang Sistem Pendidikan Nasional. J akarta: Armas Duta J aya, 1990.

Webster, Webster's New Dictionary of A merican Language. t.tp.: The World Publisshing Company, 1964.

Webster. Webster's New International Dictionary. t.tp.: GG Merriam Company, 1953. 